Tomaž Pavlin ${ }^{*}$

\title{
Attainment of Slovenian Independence and Sport
}

\section{IZVLE $\check{C} K$ \\ SLOVENSKA OSAMOSVOJITEV IN ŠPORT}

Šport je tekom druge polovice 19. in nato 20. stoletja postal sestavni del slovenske narodne biti in kulture. Resda sta se kot krovna izraza tega družbenega področja v daljšem obdobju uporabljala izraza telesna vzgoja in telesna kultura, organizacijsko pa je bil in je utemeljen na društvenem organiziranju. V kontekstu organiziranja se je po drugi svetovni vojni vzpostavila specifićna struktura, konec osemdesetih let 20. stoletja pa so nastopile prve spremembe, pojmovne in organizacijske, $z$ razglasitvijo samostojnosti pa nadaljnje in vstop v mednarodni prostor. Prispevek odstira kljucne trenutke predosamosvojitve in prve korake v pripravo športne samostojnosti s svojim nacionalnim olimpijskim komitejem ter nato junijsko osamosvojitev 1991 in odmev v športu, nato pa kratko nakaže skladno s politično-ekonomsko tranzicijo dileme športnega reorganiziranja in novega razmerja javno-društveno po osamosvojitvi.

Ključne besede: šport, osamosvojitev, Slovenija, Olimpijski komite Slovenije

\section{ABSTRACT}

During the second half of the $19^{\text {th }}$ and then in the $20^{\text {th }}$ century, sport has become an integral part of the Slovenian national essence and culture. It is true that for a long time the expressions "physical education" and "physical culture" were used as umbrella terms for this social area, while in the organisational sense sport was and remains based on organisation in clubs. In the context of organisation a specific structure had been set up after World War II. At the end of the 1980s the first conceptual and organisational changes were introduced, while with the declaration of the Slovenian independence further changes and entry into the international space were implemented. The following contribution reveals the key moments of pre-independence and the first steps towards the preparation of the independence of sports by means of the Slovenian own Olympic Committee, followed by the declaration of independence in June 1991 and its implications for sport. Then the contribution shortly outlines the dilemmas of sport reorganisation stemming from the political-economic transition and the new relationship between the public and club sport after the independence.

Keywords: sport, independence, Slovenia, Slovenian Olympic Committee

* Assistant Professor, PhD, University of Ljubljana, Faculty of Sport, Gortanova 22, SI-1000 Ljubljana, tomaz.pavlin@fsp.uni-lj.si 
At the $20^{\text {th }}$ anniversary of the Slovenian Olympic Committee \& Sports Association, Dr Janez Kocijančič, its President at that time, emphasised in his introductory "assessment" that Slovenian sport "has not 'entered' its own country without very solid foundations and traditions, but I can nevertheless safely state that it has seen its true renaissance in the period of the independent Slovenia" ${ }^{1}$, which is amply shown by the medals from the Olympic and other competitions that do away with the stereotypical image of Slovenians as individual athletes, primarily skiers. Let me just quickly emphasise the qualifications of the Slovenian football team for the European (2000) and World Cup (2002, 2010); or the qualifications of the hockey team for the Olympics in Sochi (2014) and again for the upcoming 2018 Olympics; the silver medal of the handball team at the European Championship in Ljubljana in 2004; the newest silver medal of the volleyball team at the European Championship in 2015; and the fourth place of the basketball team at the 2009 World Championship. The individual achievements of clubs at the European club level are also a part of these successes. It is a fact that sports were - and still are - a well-developed and popular part of the leisure time of Slovenians, whether competitive or recreational. According to the assessments more than half of the Slovenian population of various ages and genders supposedly regularly or periodically engage in sports, meaning that Slovenia is ranked quite high also in the European scope. The green landscape and cities which can compensate for the lack of infrastructure as well as the "enthusiasm" and zeal that influences the recreational, amateur, voluntary or professional activities has, in the past, connected sports with the national question and national identity. This also opens the question of acknowledging and evaluating the influence of sports on the formation of the national awareness and statehood, as budgetary financing in the middle of the 1990s was at the tail end of Europe, while on the other hand Slovenian athletes were, paradoxically, directly proportional in their competitive achievements. How can we explain this, especially in light of the fact that financing within the sports budget increased for unorganised or public sports, and why? Transition?

Slovenian sport has a long tradition and continuity, if we look at its organisational foundations and structure. Already in 1862 an initiative to establish a "gymnastic" society in Ljubljana was undertaken in the enthusiastic atmosphere of restoring the constitutional life in what was then the Austrian Empire. Thus the Južni Sokol organisation was established in October 1863. In view of its name, which refers to a similar Sokol organisation from Prague, literature often tends to stereotypically reiterate that this organisation was modelled after the Czech one. Admittedly it is true that among the Habsburg Slavs the first Sokol organisation was founded in Prague in February 1862 and that the Czechs represented a cultural model for Slovenians in the period until World War I. However, it is also a fact that gymnastic activities had

1 Janez Kocijančič, "Uvodne misli," [Introductory Thoughts] in: Olimpijski komite Slovenije-Združenje športnih zvez 1991-2011. Športna zgodba, stkana iz dejavnosti tisočev, ed. Tomaž Pavlin (Ljubljana: OKS-ZŠZ, 2011), unpaginated pages. 
been well-known in Ljubljana already before 1862, and that the citizens of Ljubljana engaged in sports independently or also unaware of the developments in Prague. Furthermore, it was nothing new for the people of Ljubljana to organise themselves in societies. As it happened, the first societies had already been established during the "Spring of Nations", while a year before the aforementioned gymnastic initiative the so-called Čitalnica society had been established, which had brought together athletic enthusiasts as well. Athletes came together in their own society, similar to the Citalnica society. They contacted the northern Czech ‘brothers) and named their organisation Južni Sokol (Southern Sokol) in light of the contemporaneous PanSlavism, while their expert knowledge was based on the inventiveness of the people of Ljubljana. ${ }^{2}$ The gymnastic society was an indicator of the physical culture life of Slovenians, which had already developed before World War I when cycling, mountaineering as well as sports that spread especially in the interwar period had already been organised in a similar way as gymnastics. Thus physical culture became a distinctive activity of Slovenians, in the organisational sense - in view of the common Yugoslav state after World War I - integrated in the Yugoslav state organisations and consequently into international sports. Similarly as after the turning point in the years 1918 and 1919, in 1990 and 1991 athletes had to face a question of how to proceed, but this time enriched by the tradition as well as their international distinctiveness.

\section{The Pre-independence Period}

The story of the emancipation of sports includes, on the one hand, the political process in the second half of the 1980s and the Yugoslav dissolution as well as the simultaneous question of whether - or how - the political radicalisation was reflected in sports. On the other hand we have to take into account the attainment of independence, dissolution of Yugoslavia, and international recognition and integration. When studying the events in the 1980s we should also look at, firstly, the state sport organisation and the developments in the state sport associations, and, secondly, for example, the competitions in the leagues where the national and political confrontation was reflected in fandom and incidents. Thus, for example, the Olimpija ice hockey team from Ljubljana was already in the season 1985/86 - after the match against Crvena zvezda from Belgrade in the completely full Tivoli Hall in Ljubljana - punished with a one-month ban on playing in the home Tivoli Hall due to a "nationalist" cheering incident. Meanwhile, elsewhere in Yugoslavia the nationalist cheering incidents culminated especially at the football derbies, particularly with the conflict between the fans of Dinamo from Zagreb and Crvena zvezda from Belgrade in Zagreb in 1990, which represented a sinister precursor to the subsequent military conflicts.

2 Tomaž Pavlin, "Dajati pobudo, priložnost in navad pravilnim vajam," [Providing the Initiative, Opportunity and Habits for Correct Exercises] Šport, No. 3-4 (2013): 34. 
In light of the Slovenian international sport integration, focus was especially aimed at the establishment of the Slovenian Olympic Committee and its recognition as well as at the club and competitive part of the sport. However, this also included the integration of the sport administrative bodies in the European institutions, which coincided with the political changes and transformation of the republic's administrative system and bodies. In view of the political and economic change from socialism to market economy and democracy, the time after the Slovenian emancipation opened the issues or transition of the (socialist) "socially-owned" to the public and private. In sports, the transition of the 1990s was reflected in the organisational, administrative, budgetary, ownership (e.g. ownership of gymnastic facilities and other sport infrastructure), legislative (the Sports Act of 1998), and, after all, also in the terminological sense. In certain sports segments the transition had started already before 25 June 1991, e.g. organisationally also after 1989, in line with the political changes in the Republic of Slovenia and the transformation of the republic administrative bodies and budget. We should also emphasise the terminological "sportisation" in 1990, as for decades in the socialist Yugoslavia the umbrella term had been physical culture ("telesna kultura" in Slovenian and "fizička kultura" in the other republics), and this had included the subsystems of physical education, recreation and sport. Sport was the common term for recreational, amateur and professional competitive organisations and activities. Officially only the football players in the premier federal league were professionals, while otherwise the competitive systems were based on amateurism, even though various forms of professionalism were also quietly introduced in the other sports in the 1970s and 1980s. In this sense it is possible to note the shortage of historical analyses of the Yugoslav period, especially the so-called "Portorož decisions", adopted in the middle of the 1970s, which represented a sort of a transition of the contemporaneous system of sports. These decisions coincided with the constitutional changes and the introduction of self-management communities of interest, through which the financing of the sports activities was implemented while the expert questions were solved in the sports organisations. In terms of organisation, club sport was, at the level of the republic, covered by the Association of Physical Culture Organisations of Slovenia (hereinafter ZTKOS), which brought together the interests of autonomous sports associations, the Partizan ${ }^{3}$ of Slovenia association and the Alpine Association of Slovenia. The organisation at the municipal level was similar. The republic associations came together in the central Association of Physical Culture Organisations of Yugoslavia (popularly referred to as the "sofka" - from the Serbo-Croatian name "Savez organizacija fizičke kulture Jugoslavije"). The Yugoslav Olympic Committee - a member of the International Olympic Committee that replaced the older prewar Yugoslav

3 In 1952, the gymnastic association as a successor to the Sokol organisation was named Partizan (freedom fighter in World War II). In 1963 the Gymnastic Association, focused primarily on sport gymnastics, separated itself from the Partizan association; while the latter focused on general exercise and recreation. 
Olympic Board in 1947 and was not further divided into republic Olympic Committees but was a single central organisation - functioned in cooperation with the "sofka" association or even within its framework. Therefore Slovenians did not have their own national Olympic organisation in this period. The special committee for top-level sport, managed by a Slovenian, Tomislav (a.k.a. Tomo) Levovnik at the end of the 1980s, also functioned in the framework of the "sofka" association. Similarly as the Associations of Physical Culture Organisations, the republic associations of individual sports were brought together in the Yugoslav sports associations; and the latter were members of the international associations. Therefore international recognition and enrolment into the international associations meant access to international competitions, and for this the membership in state organisations was of key importance.

If we take another look at the terminology, which also today often results in problems with understanding the system and subsystems or the purpose and assessment of the whole activity: in 1990 - after several discussions, especially academic at the Faculty of Physical Culture (today the Faculty of Sport) - the term physical culture was changed to sport. This also involved the renaming of the subsystems: physical education $\rightarrow$ sport education, recreation $\rightarrow$ sport recreation, sport $\rightarrow$ (high-level, top-level) sport. At the same time sport was also a hypernym, which is a process that we cannot register in the other republics. In accordance with the above, on 5 September 1990 the ZTKOS (Association of Physical Culture Organisations of Slovenia) was renamed as the Sports Association of Slovenia (hereinafter ŠZS). However, in accordance with the democratisation the question of membership was also raised, and the Partizan of Slovenia association, for example, continued its independent path. In 1993 the Partizan of Slovenia association renamed itself as the Sports Union of Slovenia. ${ }^{4}$

The new times were supposed to be reflected in the $\check{Z} Z S$ also in the elections of its President on 25 September 1990. Šugman, President of the ŠZS, later emphasised that "also in sport elections took place: for the first time after World War II without the participation of either the state authorities or political parties"5, though, admittedly, quite a few officials or committee members were also members and/or politicians of the League of Communists and later its successor, and a comparison should be made between the sorts of sport elections through a longer time frame. After its election assembly in 1991, the ŠZS analysed the current situation with the aim of

4 Rajko Šugman, Prelomno obdobje slovenskega športa 1988-1994. Prispevki za zgodovino slovenskega športa [The Turning Point for the Slovenian Sport 1988-1994. Contributions to the History of Slovenian Sport] (Ljubljana: Fakulteta za šport, 1999), 36-56. Tomaž Pavlin, "Ni pomembno zmagati, pač se dobro boriti ali slovenska olimpijska pot," [It is Not Important to Win, but to Put Up a Good Fight or the Slovenian Olympic Path] in: Sabljanje, vešcina, tradicija, šport. Zbornik ob 100-letnici osvojitve srebrne olimpijske medalje Rudolfa Cvetka, eds. Jože Podpečnik and Simona Pörš (Ljubljana: Narodni muzej Slovenije, 2012), 94-99. Tomaž Pavlin, "Oris razvoja sokolske in partizanske organizacije na Slovenskem," [An Outline of the Development of the Sokol and Partisan Organisation in Slovenia] in: Osnove športne rekreacije, ed. Miroljub Jakovljević. (Ljubljana: Športna unija Slovenije, 2013), 17, 18.

5 Šugman, Prelomno obdobje, 44. 
"seeking the organisational forms and focus of work" ${ }^{6}$ For example, already in February 1990 Levovnik prepared a proposal on the reorganisation and formation of the Slovenian Olympic Committee, ${ }^{7}$ and a debate took place with regard to either a twofold organisation and separate sport and Olympic organisation or a single sportOlympic organisation. At that time Slovenian sport was still quite closely connected to the Yugoslav sport. In February 1991, the further preparations and financing of the top-level athletes in the context of the Olympic cycle Albertville-Barcelona 1992 were discussed at the joint meeting of the "sofka" association and the Yugoslav Olympic Committee. Among other things it was underlined that the political developments in the state should not influence the joint participation of Yugoslav athletes at important international competitions. At the same time this meant that the concept of preparations was also all-Yugoslav, and that this was supposed to ensure "optimum" preparations for all Yugoslav athletes, as there was only another year left to the Winter Olympics. In the context of the preparations, the Yugoslav athletes were also to appear in 1991at the Mediterranean Games (Athens) and the Universiade / World Student Games (Sheffield). However, despite the increasing political tensions the issue of the unresolved system of financing the Olympic candidates was still the "central problem", which had been apparent ever since the first year of the Olympic cycle and only kept getting worse. ${ }^{8}$

At the beginning of April 1991, the ŠZS informed the "sofka" association and the Yugoslav Olympic Committee about the its plans to reorganise, and that the sports organisations in Slovenia had decided "to establish a Slovenian Olympic Committee and soon appoint the initiative committee for its establishment, headed by the best Yugoslav athlete of all time - Miroslav Cerar". ${ }^{9}$ In order to ensure the continued international participation of Slovenian athletes, the ŠZS emphasised its "wishes that the Olympic Committee of Slovenia remained in the context of the Yugoslav Olympic Committee, unless the dissolution of Yugoslavia should take place". ${ }^{10}$ After that, at its session on 18 April, the Presidency of the ŠZS adopted a decision on the establishment of the Olympic Committee, appointed the Initiative Committee for the Establishment of the Olympic Committee of Slovenia, and sent a Letter of Intent to the President of the International Olympic Committee J. A. Samaranch. In June 1991 the Initiative Committee (President Miroslav Cerar, Secretary Ivo Daneu,

6 Poročilo Predsedstva ŠZS o delu v obdobju 1990-1994 [Report of the Presidency of the Sports Association of Slovenia in the Period between 1990 and 1994]. - Private archive, Tomo Levovnik.

7 Organiziranost Slovenske športne zveze (Športne zveze Slovenije) Slovenskega olimpijskega komiteja, 25. 2. 1990 [Organisation of the Slovenian Sports Association (Sports Association of Slovenia) and the Slovenian Olympic Committee, 25 February 1990]. - Private archive, Tomo Levovnik.

8 Zapisnik sa sastanka komisije za vrhunski sport i olimpijske pripreme SFKJ, 26. 2. 1991 [Minutes from the meeting of the Commission for Top-Level Sport and Olympic Preparations of the Physical Culture Association of Yugoslavia, 26 February 1991]. - Private archive, Tomo Levovnik.

9 Dopis ŠZS ZTKOJ in JOK, 10. 4. 1991 [Letter from the Sports Association of Slovenia to the Association of Physical Culture Organisations of Yugoslavia and the Yugoslav Olympic Committee, 10 April 1991]. - Private archive, Tomo Levovnik.

10 Ibid. 
members Evgen Bergant, M. Sc. Janez Kocjančič, Milan Jerman, Janez Sterle, Dr Rajko Šugman) prepared a working draft of the Olympic Committee rules, sent it to sport associations, and invited them to register their candidates for the authority bodies. After the attainment of the Slovenian independence this Committee paved the way for the establishment of the national Olympic Committee, the international Olympic recognition, and attendance of Slovenian athletes at the 1992 Winter Olympic Games in the French Albertville.

\section{Attainment of Independence and Dissolution}

With the declaration of the Slovenian independence on 25 June 1991, the process of separation from the Yugoslav associations in the field of sport began, but was prolonged by the Brioni Moratorium. On 26 June the aggression of the Yugoslav Army followed. At the time of the army attack quite a few Slovenian athletes were in the ranks of the Yugoslav teams abroad (the Mediterranean Games in Athens, the European Basketball Championship in Rome, the World Cup in kayak and canoe in Mezzano). Other athletes were at home during the summer competitions or preparing for the competition season. For example, in the autumn hockey players would compete in the newly-organised Alpine League, an international league of the best Italian, Austrian and Slovenian clubs; while skiers, as usual, would compete in the World Cup and in a little over half a year at the Winter Olympics in Albertville. Already on 27 June the ŠZS released a "recommendation" that all sports competitions in the territory of the Republic of Slovenia be postponed, and advised the Slovenian athletes not to participate at the competitions outside of Slovenia due to security reasons. ${ }^{11}$ Tomo Levovnik immediately resigned from his post as President of the Yugoslav Commission for Top-Level Sport. In his resignation note of 28 June 1991 he sternly emphasised that he was resigning "due to the brutal occupation of Slovenia and merciless killing of Slovenians by the Yugoslav Army." 12 Levovnik demanded of the Presidency of the ŠZS that it should "immediately recall all Slovenian athletes competing in the Yugoslav teams"13 due to the occupation by the Yugoslav Army. In the middle of the day on 28 June the ŠZS appealed to the Slovenian athletes that they should "leave the Yugoslav teams due to the brutal aggression of the Yugoslav Army and return home as soon as possible", as it was "offensive for the Slovenian nation that the Slovenian athletes should represent the colours of Yugoslavia at in-

11 Stališče o športnih prireditvah in nastopih slovenskih športnikov, 27. 6. 1991 [The standpoint with regard to sporting events and performances of Slovenian athletes, 27 June 1991]. - Private archive, Tomo Levovnik.

12 Dopis T. Levovnika JOK z dne 28. 6. 1991 [Letter from T. Levovnik to the Yugoslav Olympic Committee of 28 June 1991]. - Private archive, Tomo Levovnik.

13 Dopis T. Levovnika ŠZS o odpoklicu športnikov z dne 28. 6. 1991 [Letter from T. Levovnik to the Sports Association of Slovenia with regard to the recall of athletes of 28 June 1991]. - Private archive, Tomo Levovnik. 
ternational competitions in such circumstances". ${ }^{14}$ The athletes had to face a difficult decision and, as the shooter Rajmond Debevec ${ }^{15}$ later explained for the Delo newspaper, every one of them "had to make up their own mind, in accordance with their own responsibility and moral and ethical principles, regardless of the consequences, even though each athlete faced a decision that might also ruin their career. Nevertheless the vast majority decided not to compete in Yugoslav teams at these competitions anymore." 16 The (Yugoslav) team leadership tried to persuade them to stay and, according to Debevec, tried to "make them realise that the situation is nevertheless not as dire as to call for such an ... extreme step. Naturally, they (the leadership - author's note) only listened to radio Belgrade, while we have nevertheless read foreign newspapers and called home, and therefore we were better and more objectively informed." Bojan Levstik from Celje, otherwise the trainer of the Italian handball team, was of great help to them, because while the leadership claimed that "there aren't any connections with the homeland, or they are at least very difficult to establish", "Bojan's phone worked perfectly, even for collect calls to Ljubljana. Without this the situation would have been even much more difficult". Rajmond Debevec first explained his decision to leave to the member of the leadership Tomić, also the secretary of the shooting association. He connected Tomić with Levovnik using Levstik's phone, and only then Tomić "believed that this was really happening at home." As Debevec stated after his return to Slovenia, the majority of the leadership respected the decision of the Slovenian athletes not to compete. However, some of the leaders were upset and offended, and they threatened that these athletes' fate - in so far as Yugoslav team competitions were concerned - was "sealed, and that even if the situation calms down and the relations are settled, they will never again be allowed to compete in the federal selection". However, the trainers opposed such extreme notions as well. ${ }^{17}$ Similarly, Jure Zdovc left the European Basketball Championship in Rome, while Yugoslavia later played in the finals and won the European Championship.

At the beginning of July 1991 a cease fire, negotiations, and the moratorium on secession agreed to in the Brioni Declaration followed. Slovenian athletes found themselves in a difficult position. The Yugoslav state was the holder of the international sport membership in the international sport as well as the participant of international sports competitions, while the 1992 Olympics were also imminent. In the politically strenuous position, on 10 July 1991 the Expert Council of the ŠZS

14 Poziv Športne zveze slovenskim športnikom, 28. 6. 1991 [Appeal of the Sports Association to Slovenian athletes, 28 June 1991]. - Private archive, Tomo Levovnik.

15 E. B., "Naša odločitev ni mogla biti drugačna," [Our Decision Could Not be Different] Delo, 4 July 1991. Rajmond Debevec was the President of the Council of Top-Level Athletes at the Association of Physical Culture Organisations of Slovenia / Sports Association of Slovenia. In Athens he took on the role of the coordinator of the action to leave Athens and was in contact with the Sports Association of Slovenia in Ljubljana and Tomo Levovnik.

16 E. B., "Naša odločitev ni mogla biti drugačna".

17 Ibid. 
convened a joint meeting with the Council of Top-Level Athletes about the normalisation of the sport activities in the given situation. After the meeting the Expert Council of the ŠZS published an "appeal to Slovenian athletes" to remain active and emphasised "that in the time of the finalisation of the status of the Republic of Slovenia, competing for the Yugoslav state teams and in the federal championships remains completely legitimate and irreproachable", as "even a short interruption of training and maintenance of the sport regime (...) can result in a significant as well as long-term decline in athletic capability". ${ }^{18}$

After the expiry of the moratorium in the beginning of October 1991, Slovenia resumed its path towards independence and international recognition. In October the ŠZS convened an extended session and, among other things, appealed to the sport organisations to initiate a "separation" 19 from the Yugoslav sport associations and initiate the proceedings for the membership in the international sport organisations. In this context, for example the recognition in November 1991 by one of the main associations of the Winter Olympics - i.e. the International Ski Federation (FIS), where Janez Kocijančič was a member of the Presidency - was very significant.

The proceedings of the national Olympic organisation and international membership was led by the Initiative Committee. The Olympic Committee of Slovenia (hereinafter OKS) was established on 15 October 1991 with the signing of the Slovenian Olympic Document, and Janez Kocijančič was elected as its President at the founding general meeting in the middle of December. The Olympic Document was signed by 29 national sport associations of the Olympic programme, 5 associations recognised by the International Olympic Committee, and two winners of Olympic gold medals - Leon Štukelj and Miroslav Cerar. Simultaneously the Initiative Committee pursued the international recognition and the independent appearance of Slovenian athletes at the 1992 Olympics. It managed to negotiate a meeting in the middle of November with the President of the International Olympic Committee (hereinafter IOC) Juan A. Samaranch, at the seat of the IOC in Lausanne. At this important meeting the conditions for the independent participation in Alberville were agreed upon, which was related to the international political recognition of the Republic of Slovenia. According to the memories of a participant of this meeting Rajko Šugman, the "complicated international circumstances, especially in the former Soviet Union and Croatia ... demanded that the Initiative Committee be very careful with regard to the contents of the negotiations". It was agreed that the members of the delegation would inform Samaranch of the situation and explain why Slovenians would not compete under the Yugoslav flag, and they would let the President of the IOC decide. Šugman emphasises that the delegation was aware that this could also be a "double-edged sword", as Samaranch could propose that the Slovenian athletes

18 ŠZS, Strokovni svet za vrhunski šport: Poziv slovenskim športnikom [Sports Association of Slovenia, Council of Top-Level Athletes: Apeal to Slovenian Athletes]. - Private archive, Tomo Levovnik.

19 ŠZS: Vsem republiškim strokovnim organizacijam, 30. 10. 1991 [Sports Association of Slovenia: To All Professional Organisations of the Republic of Slovenia, 30 October 1991]. - Private archive, Tomo Levovnik. 
compete "with the Yugoslav athletes under the inscription Olympic Committee of Yugoslavia" or even under the Olympic flag. ${ }^{20}$

The meeting with Samaranch "behind closed doors" at the seat of the IOC took place on 18 November 1991. After the introductory diplomatic part the discussion resumed and in the end it was concluded that Slovenia would be able to compete at the Olympic Games, should it be recognised as a state by at least a few important countries. Three countries were specified: Germany, Spain and France. Samaranch advised the delegation to immediately file a request for recognition, so that he would able to refer to it at the sessions of the Executive Committee of the IOC in December 1991, while on 7 December a joint session would take place with the representatives of the winter sport disciplines - of which the FIS had already recognised the Ski Association of Slovenia. ${ }^{21}$ On 28 November the Initiative Committee, now already in the name of the OKS, and the undersigned Miroslav Cerar sent a request to Samaranch in Lausanne for the recognition and attendance at the Olympic competitions. The request emphasised that the OKS was the "representative body of all Olympic sports in the Republic of Slovenia", while the Socialist Federal Republic of Yugoslavia no longer existed, as "several sovereign states came into existence and at the time being, between the two most populated nations a most cruel and bloody war is being fought. ... Today the Republic of Slovenia maintains its status as an independent and sovereign state. It has its own undisputed territory, a homogenous population and its democratically elected multi-party government. The last soldier of the former Federal Army left Slovenia one month ago. Slovenia has its own currency and own passports, recognized already by twenty foreign states." In the following points the current and historical nation-building role of sport was emphasised, also that "during the Second World War the sporting organisations were among the founders of the National Liberation Front, successfully initiating and leading the campaign of liberation from the foreign occupation." The presence of Slovenians at the Olympic Games ever since Rudolf Cvetko in 1912 was underlined, and finally it was stated that "all associations of Olympic sports and sports recognized by IOC, signed the Slovenian Olympic Charter on 15 $5^{\text {th }}$ October 1991" and declared "their recognition of the Olympic spirit and the recognition of their obedience to the International Olympic Committee in the field of international sport." 22

At the end of 1991 and in the beginning of 1992 the Republic of Slovenia gained recognition, critical for its attendance of the Olympics, and on 17 January 1992 it received the IOC's invitation to the Olympic Games. ${ }^{23}$ Thus the Slovenian athletes appeared under the Slovenian national flag for the first time in history at the parade of nations in the Albertville's Olympic Arena. Half a year later Barcelona followed, and there the rowers won the first medals - bronze - for the independent Slovenia.

20 Šugman, Prelomno obdobje, 92, 93.

21 Ibid., 99, 100.

22 Dopis predsedniku MOK 28. 11. 1991 [Letter to the President of the International Olympic Committee, 28 November 1991]. - Private archive, Tomo Levovnik.

23 Šugman, Prelomno obdobje, 109. 
However, apart from the Olympic recognition the enrolment into the international sport associations also took place, and this completed the Slovenian international sport recognition.

\section{Dilemmas}

1991 was undoubtedly "the historical year" for the Slovenian sport, as the report of the Presidency of the ŠZS emphasises for the period between 1990 and 1994. In the organisational sense it is perhaps comparable with the events at the end of World War I, with the first Slovenian sport and territorial organisation, Yugoslav organisation, and entry into the international sport, as the Austro-Hungarian position had been quite specific. As far as the organisation of civil sport - especially of both the umbrella institutions, the OKS and the ŠZS - is concerned, 1994 is the turning point. At that time these organisations merged under the name Slovenian Olympic Committee - Association of Sports federations. The discussions in favour of and against the merging had been going on ever since 1992, and a similar situation was also notable at the European level.

However, while describing the events during the emancipation of the Slovenian sport we should also bring the attention to a parallel process: the transition of the previous municipial sports associations into public bodies or organising of new public sport bodies and the expansion of the public sphere at the state and municipal level. This later gave rise to criticism with regard to the nationalisation of sport, or - as Šugman underlined in his study Modeli športa $v$ svetu in podržavljanje športa (Models of Sport Abroad and the Nationalisation of Sport) (1999) - with regard to the "domination of the state over the civil sphere of sport", which was allegedly "one of the most repulsive forms of the state intervening in this sphere". Already in 1990 the tasks of the former self-management communities of interest were transferred to the republic or municipal bodies. The Republic Administration Act of 20 June 1991 reassigned sport in the previous physical culture sense to the newly-established Ministry of Education and Sport, Sport Division (today Sport Directorate). In 1992 the Ministry formed the Council of Experts for Sport as a consultative body for the preparation of opinions, evaluations, and practical implementation of various proposed measures. Soon the process of preparing the Sport Act was underway. It was sent to the first reading in 1995 and was rather severely criticised, especially because the authors of the Act, according to opposition, did not take the civil sphere into account, even though quite a few discussions and consultations had been organised. The journalist as well as sport professional Oto Giacomelli, who wrote for the Delo newspaper, was a stern critic and, for example, on 27 May 1996 he underlined that the state had established a "primate over sport" while only assigning a marginal role to the sphere of civil sport. The reproaches were aimed at the Ministry of Education and Sport and the Secretary of Sport at the time, Dr Janko Strel, but indirectly also at the Olympic Committee and its President, as "at the session of the Executive Committee of the OKS, which took place only a day before the first reading of the pro- 
posed Sport Act in the Parliament, we could hear significantly more reconciliatory words about the relations between the Olympic Committee and the administrative body for sport as just a few weeks earlier." ${ }^{24}$ On the basis of the above we have to ask ourselves about the division of authority between the public and private/civil sport sphere, which calls for a dedicated study, especially because the materials of the Slovenian Olympic Committee \& Sports Association have been preserved. Admittedly these materials are currently still in disarray, but this is negligible in view of the fact that in sport we far too often face a neglectful attitude to documentation and heritage as well as a shortage of primary sources.

A new hot topic in the second half of the 1990s was the Ownership Transformation of the Lottery of Slovenia Act and the establishment of the foundation for the financing of sport organisations. According to, for example, the writing of Oto Giacomelli, this was "another slap in the face of sport" (he was referring to the club sport in the context of the Slovenian Olympic Committee - Association of Sports Federations), as the proposed Act would supposedly "marginalise" the role of the club sport and thus also the majority of the "related Slovenian associations of individual sports and all the local (municipal) sport associations". ${ }^{25}$ However, it is a fact that not all sport organisations were members of the Slovenian Olympic Committee - Association of Sports Federations.

In order to ensure a fuller picture of the state of sport we should also focus on the events according to the individual sport disciplines. In many disciplines the problems were financial and administrative-organisational in nature. A few clubs even went in the red and then went bankrupt, and already in the 1990s ideas started forming about the club ownership according to, for example, the model of football clubs in Great Britain. The search for competition models was also pressing, especially in the collective sports, based either on the Slovenian space (football, handball) or on the integration at the Alpine-Panonian (hockey, volleyball) or former Yugoslav space (basketball). The competition models kept changing and they still are, like for example the most recent changes in handball. The situation in the individual sports was a bit different.

However, the situation in the recreational and "public" sport remained on par with the competitive sport, which was most exposed in the media. The former was carried out especially through the programmes or projects of the Institute for Sport, established by the state in 1994 . We have already mentioned the field of recreation in the introduction, and scientifically this field has been monitored with the studies about the sport and recreational activities of Slovenians (the last study was carried out in 2009 and the first ones already in the 1980s). The studies attested to a quite stable continuity in the field of exercise, and, as far as certain activities are concerned,

24 Oto Giacomelli, "Športni sferi obrobna vloga. Državi primat nad športom," [A Marginal Role for the Sphere of Sport. The State Primate over Sport] Delo, 27 May 1996.

25 Oto Giacomelli, "Še ena krepka zaušnica športu," [Another Slap in the Face of Sport] Delo, 2 September 1996. 
changes have been registered, e.g. the increase in recreational football in the independent Slovenia. 26

In conclusion let us emphasise another aspect of changes which we only mentioned already above. These took place at the municipal level, where the positive or negative changes were frequently the result of the political or mayor's will, which is clearly obvious from the example of the town of Domžale. ${ }^{27}$ The municipal changes shared the general principle of transforming the social into public-private, but with specific local characteristics. In certain municipalities the municipal Associations of Physical Culture Organisations or Sport Associations could be transformed into public bodies or institutions or municipal departments or even remained operational and faced the competition in the form of municipal agencies, like it happened in Ljubljana, for example. However, we also have to pay attention to the time of changes, influenced also, for example, by the Sport Act, which, among other things, provided for the regularisation of the ownership of sports facilities, which were mostly taken over by the municipalities. The gymnastic halls and athletic grounds of the Partizan societies and the Partizan Slovenije association, which transformed into the Sports Union of Slovenia in 1993, were an exception. Their ownership transformation was accompanied by the stereotype about sport tycoons, which, however, has its own history and would call for a more extensive text. The story of the property of gymnastic societies is related to the time after 1945, when the property of the Sokol organisation and the Catholic gymnastic societies was transferred to the Physical Culture Association of Slovenia in accordance with the "act on transferring the property of physical education societies to the Association of Physical Culture Societies". In accordance with the reorganisations of physical culture after 1948, in 1952 the former property of gymnastic societies was transferred to the Partizan Slovenije, and similarly other sport facilities were taken over by the Sports Association, mountaineering facilities by the Alpine Association, and so on. As the Partizan association established later, this step was urgent, as in the beginning of the 1950s - simultaneously with the nationalisation policy - municipalities started showing appetites for cooperatives and commercial organisations with the aim of appropriating the right to manage the property of gymnastic societies, claiming that it was socially-owned. With the transition after 1991, similar appetites were thwarted by the Sports Union of Slovenia, as this action blocked the aspirations of certain local societies to take over the property.

\section{Sources and Literature}

Archive sources:

- Tomislav Levovnik's private archive.

26 Krešimir Petrović, Franci Ambrožič, Boris Sila and Mojca Doupona, Športno rekreativna dejavnost v Sloveniji 1997. Primerjalna študija 1992-1997 [Sport and Recreation Activities in Slovenia 1997. A Comparative Study 1992-1997] (Ljubljana: Fakulteta za šport, 1998).

27 Domen Jarc, "Razvoj športa v občini Domžale med leti 1991-2011” [Development of Sport in the Domžale Municipality between 1991 and 2011] (diploma paper, Ljubljana, 2015). 


\section{Literature:}

- E. B. "Naša odločitev ni mogla biti drugačna." [Our Decision Could Not be Different] Delo, 4 July 1991.

- Giacomelli, Oto. "Še ena krepka zaušnica športu." [Another Slap in the Face of Sport] Delo, 2 September 1996.

- Giacomelli, Oto. "Športni sferi obrobna vloga. Državi primat nad športom.” [A Marginal Role for the Sphere of Sport. The State Primate over Sport] Delo, 27 May 1996.

- Jarc, Domen. "Razvoj športa v občini Domžale med leti 1991-2011." [Development of Sport in the Domžale Municipality between 1991 and 2011] Diploma paper, Ljubljana, 2015.

- Kocijančič, Janez. "Uvodne misli." [Introductory Thoughts] In: Olimpijski komite Slovenije-Združenje športnih zvez 1991-2011. Športna zgodba, stkana iz dejavnosti tisočev, ed. Tomaž Pavlin, introductory unpaginated pages. Ljubljana: OKS-ZŠZ, 2011.

- Pavlin, Tomaž. "Dajati pobudo, priložnost in navad pravilnim telesnim vajam." [Providing the Initiative, Opportunity and Habits for Correct Exercises] Šport, No. 3-4 (2013): 33-40.

- Pavlin, Tomaž. "Ni pomembno zmagati, pač se dobro boriti ali slovenska olimpijska pot." [It is Not Important to Win, but to Put Up a Good Fight or the Slovenian Olympic Path] In: Sabljanje, veščina, tradicija, šport. Zbornik ob 100-letnici osvojitve srebrne olimpijske medalje Rudolfa Cvetka, eds. Jože Podpečnik and Simona Pörš, 89-101. Ljubljana: Narodni muzej Slovenije, 2012.

- Pavlin, Tomaž. "Oris razvoja sokolske in partizanske organizacije ter rekreacije na Slovenskem." [An Outline of the Development of the Sokol and Partisan Organisation and Recreation in Slovenia] In: Osnove športne rekreacije, ed. Miroljub Jakovljević, 1-18. Ljubljana: Športna unija Slovenije, 2013.

- Petrović, Krešimir, Franci Ambrožič, Boris Sila and Mojca Doupona. Športno rekreativna dejavnost v Sloveniji 1997. Primerjalna študija 1992-1997 [Sport and Recreation Activities in Slovenia 1997. A Comparative Study 1992-1997]. Ljubljana: Fakulteta za šport, 1998.

- Šugman, Rajko. "Modeli športa v svetu in podržavljanje športa pri nas." [Models of Sport Abroad and the Nationalisation of Sport in Slovenia] In: Stanje, odnosi in vrednote v slovenskem športu, eds. Aleks L. Vest and Rajko Šugman, 9-21. Ljubljana: OKS-ZŠZ, 1999.

- Šugman, Rajko. Prelomno obdobje slovenskega športa 1988-1994. Prispevki za zgodovino slovenskega športa. [The Turning Point for the Slovenian Sport 1988-1994. Contributions to the History of Slovenian Sport] Ljubljana: Fakulteta za šport, 1999.

\begin{tabular}{c} 
Tomaž Pavlin \\
\hline SLOVENSKA OSAMOSVOJITEV IN ŠPORT \\
\hline P O V Z E T E K \\
\hline
\end{tabular}

Slovenski šport je bil v jugoslovanski državi v republiškem merilu organizacijsko-strokovno osredotočen v Zvezi telesnokulturnih organizacij Slovenije, na drugi strani pa tesno vpet v jugoslovanskega in preko njega v mednarodni, saj so bile jugoslovanske zveze nosilke mednarodnih nastopov. Septembra 1990 se je Zveza telesnokulturnih organizacij Slovenije preimenovala v Športno zvezo Slovenije (ŠZS) in pripravljala reorganizacijo z ustanovitvijo nacionalnega olimpijskega telesa. Krovni izraz za to področje je bil vse do leta 1990 telesna kultura, nakar se je zgodila (terminološka) tranzicija v šport. $S$ političnim zaostrovanjem so tudi v ŠZS razpravljali o nadaljnji športni poti in aprila 1991 je ŠZS obvestila jugoslovansko centralno zvezo o reorganiziranju z olimpijskim odborom, vendar v jugoslovanskem okviru. Z agresijo Jugoslovanske armade po razglasitvi samostojnosti junija 1991 je ŠZS pozvala slovenske športnike, da zapustijo jugoslovanske reprezentance, po zaključku brionskega moratorija pa je pozvala športne organizacije $\mathrm{k}$ razdružitvi $\mathrm{z}$ jugoslovanskimi zvezami in da sprožijo postopke priznanja v mednarodnih športnih zvezah; pri tem je bilo pomenljivo mednarodno smučarsko priznanje novembra 1991. V primeru olimpijskega priznanja je ključno delo odigral Iniciativni odbor za ustanovitev nacionalnega olimpijskega telesa, ki se je novembra 1991 sestal tudi s predsednikom Mednarodnega olimpijskega komiteja J.A. Samaranchom, doma pa oktobra pripravil ustanovitev Olimpijskega komi- 
teja Slovenije (OKS). Po mednarodnem priznavanju slovenske države konec leta 1991 in v začetku leta 1992 je OKS dobil povabilo na olimpijske igre v letu 1992.

Kot je v letu 1994 poudarilo poročilo predsedstva ŠZS, je bilo leto 1991 nedvomno "zgodovinsko leto« slovenskega športa, vendar pa je vzporedno skladno s politično-ekonomsko tranzicijo potekal tudi proces vezan na tranzicijo družbenega v javno-zasebno. Naloge bivših (socialističnih) samoupravnih interesnih skupnosti so bile že v letu 1990 prenesene na republiške ali občinske organe, zakon o republiški upravi junija 1991 pa je šport prenesel na novo oblikovano Ministrstvo za šolstvo in šport, Sektor za šport (danes direktorat). $V$ devetdesetih letih je nastopilo tudi vprašanje Zakona o športu s polemikami o podržavljanju športa in delitvijo oblasti v športu med javno in zasebno/civilno sfero, medtem ko so športne panoge iskale in vzpostavljale tekmovalne modele in se soočale s prvimi finančnimi težavami. Prispevek se osredotoča na pomembne korake športne osamosvojitve, športno reorganiziranje in snovanje nacionalnega olimpijskega komiteja, junijsko osamosvojitev 1991 in odmev v športu, nato pa nakaže dileme športne tranzicije. 